\title{
The Role of Local Materials in Creating A Meaningful Visual Experiences in Urban Public Facilities
}

\author{
Triandriani Mustikawati ${ }^{1, *}$, Maria M.C Sengke ${ }^{1}$, Paramita Atmodiwirjo ${ }^{1}$, and Yandi Andri Yatmo ${ }^{1}$ \\ ${ }^{1}$ Department of Architecture, Faculty of Engineering, Universitas Indonesia, Kampus Baru UI, Depok 16424, Indonesia
}

\begin{abstract}
This paper discusses visibility potential of local material products that are used as part of architectural spaces. Knowing the visibility potential of local materials is essential to create visual clarity that supports the ease of spatial orientation and navigation and provides a meaningful visual experience in urban public facilities. This study aims at finding the property quality of objects from local materials that contribute to the visibility potential. Field studies were conducted to identify different types of products from local materials and their characteristics associated with the quality of space experience. The visibility analysis using 3D software program then was carried out by simulating the placement of objects as elements of space in a particular spatial configuration. The result reveals several patterns of possible placement of objects from local materials that have the best potential to enhance visibility. These patterns can add to the alternative vocabulary in architectural design. Keywords: visibility potential, local material, visibility analysis, visual experience.
\end{abstract}

\section{Introduction}

Local materials have been widely used as part of architectural space for several reasons. The use of local material has been mostly associated with the issue of sustainability and ecological aspect. Some studies have discussed the use of local materials concerning the use of energy $[1,2,3,4,5]$. Other study discussed the use of local materials in creating thermal comfort in building interior $[6,7]$. All of these studies emphasize the role of local materials in creating environmental sustainability. Related with the aesthetic aspect, the use of local materials in a traditional and contemporary building can also enhance the visual look of the building by displaying the strong local character of the building. It usually reflects the environmental condition of the place where the building is located, thus reveal the identity space.

This paper tries to propose another idea of using the local materials as a part of architectural space in public building by emphasizing on the visibility potential of local materials. This study aims to find the property quality of objects from local materials that contribute to its visibility potential. Local materials usually have the salient feature that creates contrast compared to other contemporary material. This saliency is one of the factors that make object has the potential to be more visible, attractive, thus easier to remembered [8]. A salient object is important to be used as landmarks, the point of references that play essential roles in building navigation or wayfinding.
In this study, the object of local material will be put as part of interior space. This paper will discuss the visibility of objects of local materials that are placed in some decision points in a corridor of a building. Decision points are points in circulation space where people likely need a cue to guide them which direction to take [9]. By a simulation approach, we will try to find out the relation between the placement of objects, the distance of the observer and the level of visibility of object as a result. We intend to use the visibility potential of local material as cues to create an imageable space that "heightens the potential depth and intensity of human spatial experience" [10].

\section{Method}

This paper was based on a study of local material from field survey at some workshops on clay, as one of the local materials that are still easily found and used in Central Java, Indonesia. From the data collected we identified types and characteristics of objects produced from local material. The visual characteristics of these objects were recorded, consisting of shape, color, texture. Their possible application as the element of space was also noted, including wall, floor, ceiling or standalone object.

A visibility analysis by simulation then was conducted. The object of local material was assumed as part of architectural space. As for setting models, some different space configurations that represent decision points in indoor public space were composed. Different

\footnotetext{
* Corresponding author: anisajid@gmail.com
} 
spatial forms had been indicated to produce different wayfinding behavior [9]. This paper will only show the result of the simulation at one of the decision point space configuration, the T- shape closed corridor with $2.4 \mathrm{~m}$ wide.

The placement of an object, as one of the factors that could affect the visibility of object become the variable of study. In this paper, the object of study is placed on three locations on the wall as a $1.2 \mathrm{~m}$ rectangular plane that stretched from the floor up to the ceiling. This plane represented any form and kind of placement of the object of local material applied to the wall. The first and second location is on one side of the wall at the end of the corridor A, and the second one is on the wall that exactly at the intersection of corridor $\mathrm{A}$ and $\mathrm{B}$.

The visibility study from 6 different locations of the observer was conducted to see how the observer will see each object. The observer was assumed to stand in the center of each corridor, with three different distances from the intersection of the corridors. The visibility was assumed to be seen from the frontal view from two different angles of view, 30 degrees and 60 degrees. The 30 degrees range is the human angle of view that to see and distinguish shapes, while 60 degrees range is the angle of view to see and distinguish color. The image of the view from each simulation was captured using Rhinoceros 3D, and the visible regions were calculated using MatLab. Table 1. shows 12 simulations conducted in this study.

Table 1 . The visibility study simulations

\begin{tabular}{|c|c|c|c|c|}
\hline No & Codes & Corridor & Position & $\begin{array}{c}\text { Angle of } \\
\text { view }\end{array}$ \\
\hline 1 & A1.30 & \multirow{6}{*}{ A } & 1 & $30^{\circ}$ \\
\hline 2 & A2.30 & & 2 & $30^{\circ}$ \\
\hline 3 & A3.30 & & 3 & $30^{\circ}$ \\
\hline 4 & A1.60 & & $\frac{3}{1}$ & $60^{\circ}$ \\
\hline 5 & $\mathrm{~A} 2.60$ & & 2 & $60^{\circ}$ \\
\hline 6 & A3.60 & & 3 & $60^{\circ}$ \\
\hline 7 & B1.30 & \multirow{6}{*}{ B } & 1 & $30^{\circ}$ \\
\hline 8 & B2.30 & & 2 & $30^{\circ}$ \\
\hline 9 & B3.30 & & 3 & $30^{\circ}$ \\
\hline 10 & B1.60 & & 1 & $60^{\circ}$ \\
\hline 11 & B2.60 & & 2 & $60^{\circ}$ \\
\hline 12 & B3.60 & & 3 & $60^{\circ}$ \\
\hline
\end{tabular}

\section{Result}

\subsection{Object of local materials}

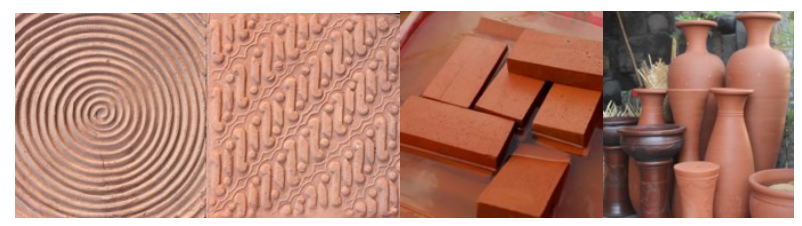

Figure 1. Examples of local material objects as wayfinding cues

Clay is one of the local materials that are still widely used in Indonesia. Indonesia has different kind of soil that made it has a rich variety of clay and objects that can be produced from this material. From the field studies to some workshops on clay products in Central Java, we find out four types of objects produced from clay. They are bricks, roof tile, terracotta tile, and pottery. Each type of objects has many variants depending on the locations of its origin. Table 2 shows the type of objects from clay, their characteristics, and possible applications.

Table 2. Types of objects from clay

\begin{tabular}{|l|l|l|}
\hline $\begin{array}{l}\text { Types of } \\
\text { objects }\end{array}$ & Visual Characteristics & Possible application \\
\hline Brick & $\begin{array}{l}\text { Modular object; Rectangular } \\
\text { volume with 6 surfaces of display } \\
\text { Color: yellowish brown, reddish } \\
\text { brown (varied) } \\
\text { Texture: smooth to coarse }\end{array}$ & $\begin{array}{l}\text { Exposed wall with } \\
\text { variety pattern of } \\
\text { installation (exterior and } \\
\text { interior) }\end{array}$ \\
\hline Roof tile & $\begin{array}{l}\text { Modular object ; Rectangular plane } \\
\text { with 1 surface of display } \\
\text { Color: orange, reddish brown, dark } \\
\text { brown (varied) } \\
\text { Texture: smooth, curvy surface }\end{array}$ & $\begin{array}{l}\text { Roof coverings } \\
\text { (exterior) ; Part of wall } \\
\text { coverings with variety } \\
\text { pattern of installation } \\
\text { (interior) }\end{array}$ \\
\hline $\begin{array}{l}\text { Terra } \\
\text { cotta tile }\end{array}$ & $\begin{array}{l}\text { Modular object ; Rectangular and } \\
\text { square plane with 1 surface of } \\
\text { display } \\
\text { Color: Terracotta } \\
\text { Texture: smooth, patterned texture } \\
\text { (varied) }\end{array}$ & $\begin{array}{l}\text { Part of wall coverings } \\
\text { with variety pattern of } \\
\text { installation (interior) } \\
\text { Floor covering (interior } \\
\text { and exterior) }\end{array}$ \\
\hline Pottery & $\begin{array}{l}\text { Single/stand-alone object (vase, } \\
\text { barrel, etc) } \\
\text { Variety of shape, color, texture }\end{array}$ & $\begin{array}{l}\text { Artwork applied on wall } \\
\text { or stand-alone object in } \\
\text { space (interior and } \\
\text { exterior) }\end{array}$ \\
\hline
\end{tabular}

\subsection{The visibility of objects}

The visibility of an object was measured from corridor A and B. On each corridor the observer was placed on three positions. $4.8 \mathrm{~m}$ back from the end of the corridor, $2.4 \mathrm{~m}$ back from the end of the corridor and right on the end line of the corridor. The angles of view were 30 degrees and 60 degrees.

The visibility of objects from 30 degrees angle of view on corridor A can be seen in Table 3. The table informs us that the broadest region area for the wall with local material was obtained when the observer stands on position A3 (nearest to the front wall). However, the observer on position A2 and A3 can only see one object. The objects on two different locations can occur in the observer's view if the observer sees it from position A1 (furthest to the corridor's end).

Table 3. The visibility of objects from 30 degrees angle of view on corridor A

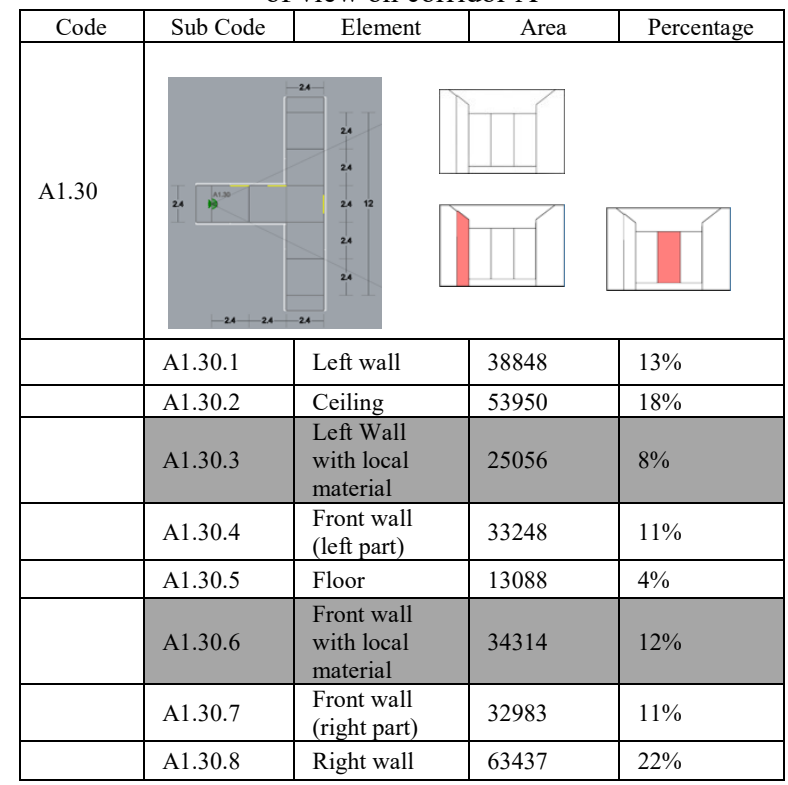




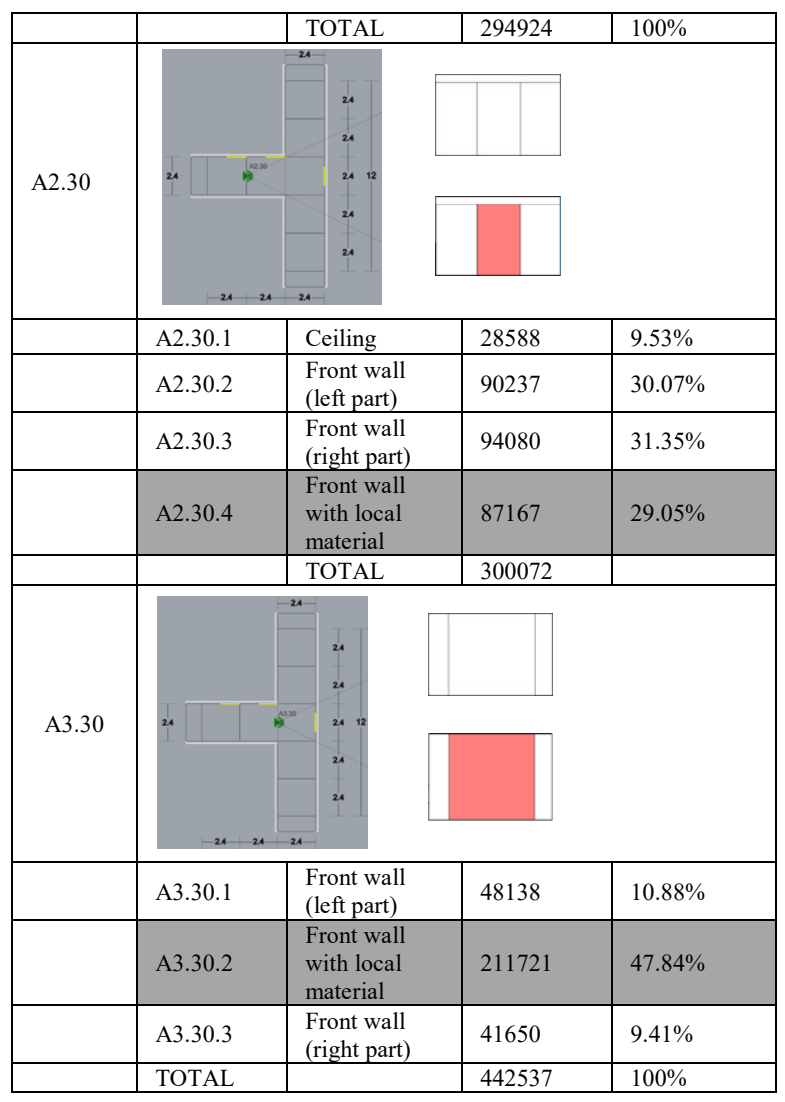

The visibility of objects from 30 degrees angle of view on corridor B can be seen in Table 4 . The visibility of an object in corridor B gave a different result. At position $\mathrm{B} 1$ and $\mathrm{B} 2$, the observer can see local material on the wall in both locations. However, at position B3 the observer cannot see any object of local material.

Table 4. The visibility of objects from 30 degrees angle of view on corridor B

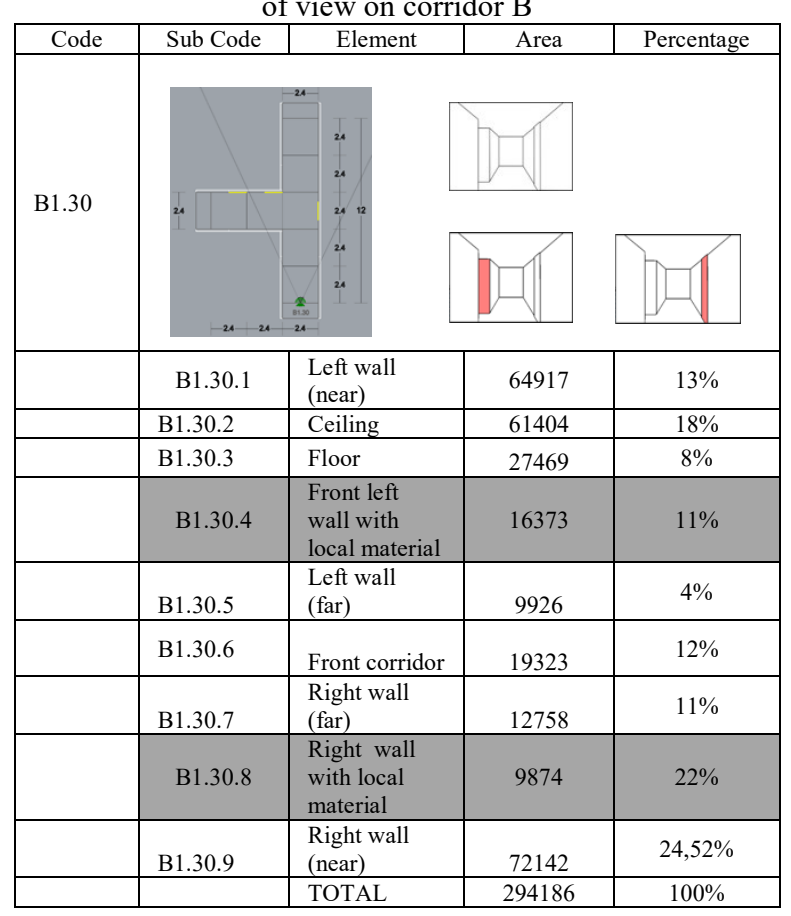

\begin{tabular}{|c|c|c|c|c|}
\hline \multirow{10}{*}{ B2.30 } & 2 & $4: 2$ & & \\
\hline & B2.30.1 & Ceiling & 66908 & $22.59 \%$ \\
\hline & B2.30.2 & $\begin{array}{l}\text { Front left } \\
\text { wall with } \\
\text { local material }\end{array}$ & 56397 & $19.04 \%$ \\
\hline & B2.30.3 & $\begin{array}{l}\begin{array}{l}\text { Left wall } \\
\text { (far) }\end{array} \\
\end{array}$ & 28217 & $9.53 \%$ \\
\hline & B2.30.4 & Floor & 22695 & $7.66 \%$ \\
\hline & B2.30.5 & Front corridor & 29580 & $9.99 \%$ \\
\hline & B2.30.6 & \begin{tabular}{|l|}
$\begin{array}{l}\text { Right wall } \\
\text { (far) }\end{array}$ \\
\end{tabular} & 36019 & $12.16 \%$ \\
\hline & B2.30.7 & $\begin{array}{l}\text { Right wall } \\
\text { with local } \\
\text { material }\end{array}$ & 35936 & $12.13 \%$ \\
\hline & B2.30.8 & \begin{tabular}{|l}
$\begin{array}{l}\text { Right wall } \\
\text { (near) }\end{array}$ \\
\end{tabular} & 20400 & $6.89 \%$ \\
\hline & & TOTAL & 296152 & $100 \%$ \\
\hline \multirow[t]{7}{*}{ B3.30 } & थ & 24 12 & & \\
\hline & B3.30.1 & $\begin{array}{l}\text { Left wall } \\
\text { (far) }\end{array}$ & 89118 & $29.90 \%$ \\
\hline & B3.30.2 & Ceiling & 55179 & $18.52 \%$ \\
\hline & B3.30.3 & Floor & 15940 & $5.35 \%$ \\
\hline & B3.30.4 & Front corridor & 49219 & $16.52 \%$ \\
\hline & B3.30.5 & $\begin{array}{l}\text { Right wall } \\
\text { (far) }\end{array}$ & 88561 & $29.72 \%$ \\
\hline & & TOTAL & 298017 & $100 \%$ \\
\hline
\end{tabular}

The visibility of objects from 60 degrees angle of view on corridor A can be seen in Table 5. At 60 degree angle of view, the observer can have a broader view. At all positions, the observer can see the object of local material. Position A1 and A2 made the observer see two locations of the object, whereas at position A3 only one location of the object can be seen.

Table 5. The visibility of objects from 60 degrees angle of view on corridor $\mathrm{A}$

\begin{tabular}{|c|c|c|c|c|}
\hline Code & Sub Code & Element & Area & Percentage \\
\hline \multirow{9}{*}{ A 1.60} & 24 & 2412 & & \\
\hline & A1.60.1 & Left wall & 1275 & $0.43 \%$ \\
\hline & A1.60.2 & $\begin{array}{l}\text { Left wall with } \\
\text { local material }\end{array}$ & 69510 & $23.49 \%$ \\
\hline & A1.60.3 & Ceiling & 62861 & $21.24 \%$ \\
\hline & A1.60.4 & Left wall & 15844 & $5.35 \%$ \\
\hline & A1.60.5 & Floor & 29086 & $9.83 \%$ \\
\hline & A1.60.6 & $\begin{array}{l}\text { Left wall with } \\
\text { local material }\end{array}$ & 6439 & $2.18 \%$ \\
\hline & A1.60.7 & $\begin{array}{l}\text { Front wall (left } \\
\text { part) }\end{array}$ & 6840 & $2.31 \%$ \\
\hline & A1.60.8 & $\begin{array}{l}\text { Front wall with } \\
\text { local material }\end{array}$ & 6840 & $2.31 \%$ \\
\hline
\end{tabular}




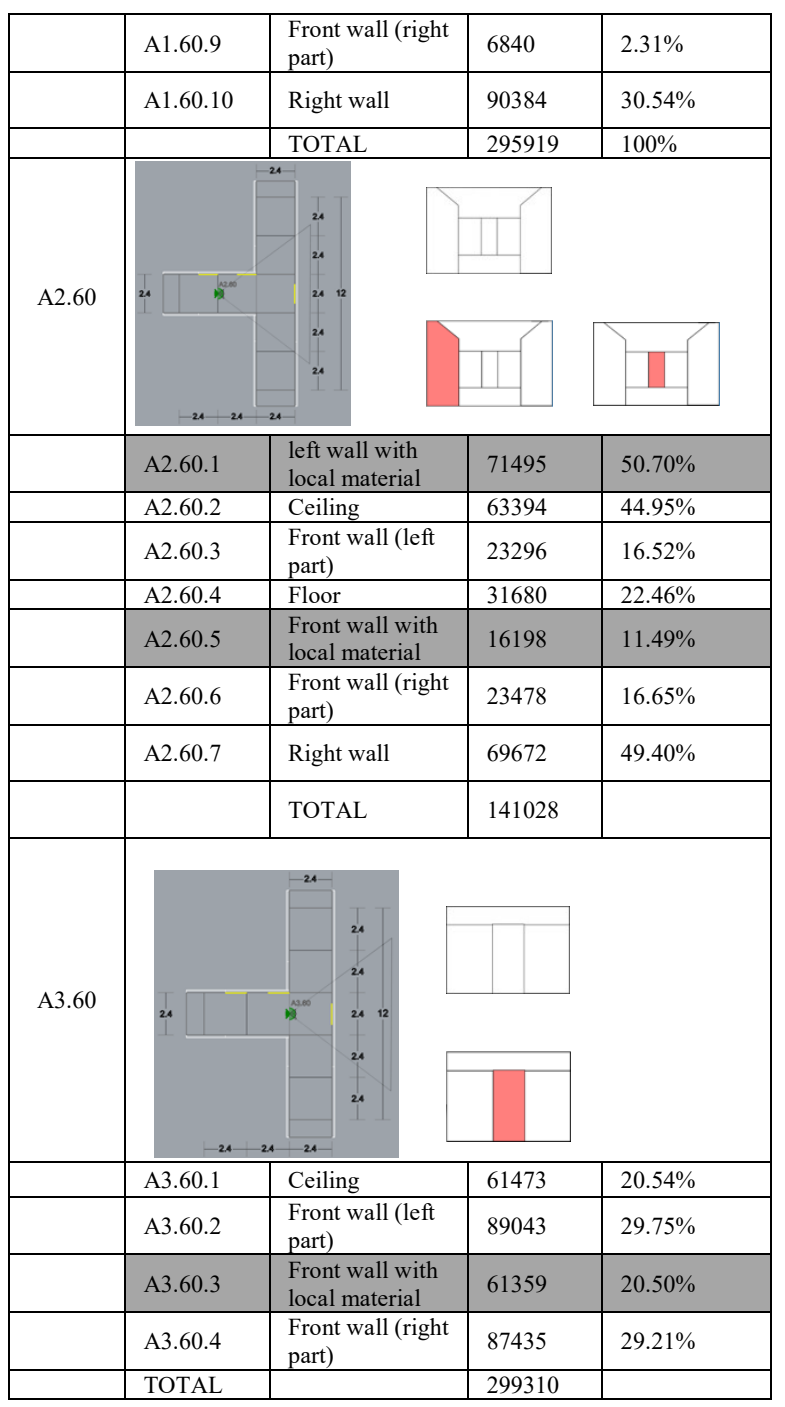

The visibility of objects from 60 degrees angle of view on corridor B can be seen in Table 6. At 60 degrees angle of view, the observer can see all the two objects on all the position (B1, B2, B3). The region area for the wall with local material varies from $1,85 \%(\mathrm{~B} 1.60 .8)$ to $42,69 \%(B 3.60 .2)$

Table 6. The visibility of objects from 60 degrees angle of view on corridor B

\begin{tabular}{|c|c|c|c|c|}
\hline Code & Sub Code & Element & Area & Percentage \\
\hline \multirow[t]{8}{*}{ B1.60 } & 24 & 2412 & & \\
\hline & B1.60.1 & $\begin{array}{l}\text { Left wall } \\
\text { (near) }\end{array}$ & 93491 & $90.23 \%$ \\
\hline & B1.60.2 & Ceiling & 63452 & $61.24 \%$ \\
\hline & B1.60.3 & Floor & 31485 & $30.39 \%$ \\
\hline & B1.60.4 & $\begin{array}{l}\text { Front left } \\
\text { wall with } \\
\text { local material }\end{array}$ & 3179 & $3.07 \%$ \\
\hline & B1.60.5 & $\begin{array}{l}\text { Left wall } \\
\text { (far) }\end{array}$ & 2173 & $2.10 \%$ \\
\hline & B1.60.6 & Front corridor & 4095 & $3.95 \%$ \\
\hline & B1.60.7 & $\begin{array}{l}\text { Right wall } \\
\text { (far) }\end{array}$ & 2662 & $2.57 \%$ \\
\hline
\end{tabular}

\begin{tabular}{|c|c|c|c|c|}
\hline & B1.60.8 & $\begin{array}{l}\text { Right wall } \\
\text { with local } \\
\text { material }\end{array}$ & 1914 & $1.85 \%$ \\
\hline \multirow{13}{*}{ B2.60 } & B1.60.9 & $\begin{array}{l}\text { Right wall } \\
\text { (near) }\end{array}$ & 94938 & $91.63 \%$ \\
\hline & & TOTAL & 103609 & $100 \%$ \\
\hline & & & & \\
\hline & B2.60.1 & $\begin{array}{l}\begin{array}{l}\text { Left wall } \\
\text { (near) }\end{array} \\
\end{array}$ & 69421 & $65.84 \%$ \\
\hline & B2.60.2 & Ceiling & 65670 & $62.28 \%$ \\
\hline & B2.60.3 & Floor & 34748 & $32.96 \%$ \\
\hline & B2.60.4 & $\begin{array}{l}\text { Front left } \\
\text { wall with } \\
\text { local material }\end{array}$ & 15737 & $14.93 \%$ \\
\hline & B2.60.5 & $\begin{array}{l}\text { Left wall } \\
\text { (far) }\end{array}$ & 5997 & $5.69 \%$ \\
\hline & B2.60.6 & Front corridor & 6240 & $5.92 \%$ \\
\hline & B2.60.7 & $\begin{array}{l}\text { Right wall } \\
\text { (far) }\end{array}$ & 8018 & $7.60 \%$ \\
\hline & B2.60.8 & $\begin{array}{l}\text { Right wall } \\
\text { with local } \\
\text { material } \\
\end{array}$ & 10747 & $10.19 \%$ \\
\hline & B2.60.9 & $\begin{array}{l}\begin{array}{l}\text { Right wall } \\
\text { (near) }\end{array} \\
\end{array}$ & 80435 & $76.29 \%$ \\
\hline & & TOTAL & 105440 & $100 \%$ \\
\hline \multirow[t]{10}{*}{ B3.60 } & 24 & 2412 & & \\
\hline & & 24 & & \\
\hline & B3.60.1 & Ceiling & 71791 & $52.26 \%$ \\
\hline & B3.60.2 & $\begin{array}{l}\text { Front left } \\
\text { wall with } \\
\text { local material } \\
\end{array}$ & 58638 & $42.69 \%$ \\
\hline & B3.60.3 & $\begin{array}{l}\text { Left wall } \\
\text { (far) }\end{array}$ & 29023 & $21.13 \%$ \\
\hline & B3.60.4 & Floor & 28839 & $20.99 \%$ \\
\hline & B3.60.5 & Front corridor & 10608 & $7.72 \%$ \\
\hline & B3.60.6 & $\begin{array}{l}\begin{array}{l}\text { Right wall } \\
\text { (far) }\end{array} \\
\end{array}$ & 48726 & $35.47 \%$ \\
\hline & B3.60.7 & $\begin{array}{l}\text { Right wall } \\
\text { with local } \\
\text { material }\end{array}$ & 49195 & $35.81 \%$ \\
\hline & TOTAL & & 137368 & \\
\hline
\end{tabular}

\section{Discussion}

The study shows that the visibility of objects will be influenced by distance and angle of view. At different distances $(4.8 \mathrm{~m}, 2.4 \mathrm{~m}$ and right on the end line of the corridor), the wall with the local material will be seen differently. Some studies of visibility also shown from where an object can be visible to the observer [11,12]. This study showed not only where an object can be visible by the observer, but also how visible the object is by measuring the region area using MatLab.

This study also shows how spatial configuration took part in enabling the object to be visible. At the T-shape intersection corridor where one of the corridors stops, 
being in the other corridor can give a possibility to see more object on the wall. Walking to approach the end of the corridor where the corridors intersect, will give a focus to only one location of the object, that is at the front view. The effect of spatial configuration on mobile visibility had been discussed before by James Gibson [13]. Gibson argued that every configuration of place constitutes a vista. So, when one moves in a corridor that at the end intersects with another corridor, it will make him close the vista behind and open up the vista ahead. The wall at the end of the corridor makes an occluding edge that will hide any vista on the front. However, as an observer move ahead approaching the intersection, the hidden vista will be opened up.

\section{Conclusion}

In measuring the visibility of objects, the configuration of space should be taken into consideration. In this initial study, a simple plan of a corridor is used as a setting. Further study should be conducted by including more detailed elements. This study also considers the objects of local material in their basic shape. More specific characteristics of an object can be added to generate a more comprehensive result.

Local materials produce a variety of objects that will relate to how these objects can be applied in indoor space and how these objects have the visibility potential. In adding elements of local materials as indoor landmarks within the circulation space, it is important to consider the configuration of space, since it will affect the visibility of object at a certain point.

\section{Acknowledgments}

This publication is supported by the United States Agency for International Development (USAID) through the Sustainable Higher Education Research Alliance (SHERA) Program for Universitas Indonesia's Scientific Modeling, Application, Research, and Training for Citycentered Innovation and Technology (SMART CITY) Project, Grant \#AID-497-A-1600004, Sub Grant \#IIE00000078-UI-1.

\section{References}

1. D. J. Harris, Build. Environ, 34(6), 751-758, (1999)

2. J.C.Morel, A. Mesbah, M.Oggero, P.Walker, Build. Environ., 36(10), 1119-1126, (2001)

3. N.Huberman, D. Pearlmutter, Energy Build., 40(5), 837-848, (2008)

4. N Rajagopalan, M.M Bilec, and A. E. Landis, $J$ Green Build, 5(3), 95-106, (2010)

5. I.Z. Bribián, A.V. Capilla, A.A. Usón, Build. Environ., 46(5), 1133-1140, (2011)

6. S.M.A. Bekkouche, T. Benouaz, M.K. Cherier, M. Hamdani, N. Benamrane, M.R. Yaiche, Constr Build Mater, 52, 59-70, (2014)

7. R.Bassiouny, M.R.Ali, E. S. H. NourEldeen, Journal of Building Engineering, 5, 158-164, (2016)
8. J. Krukar, Behav Sci, 4(3), 181-201, (2014)

9. S. Y. Tzeng, J.S. Huang, J Asian Archit Build, 8(2), 453-460, (2009)

10. K. Lynch, The image of the city (1960)

11. I. Delikostidis, J. Engel, B. Retsios, C.P. van Elzakker, M.J. Kraak, J. Döllner, J Navigation, 66(4), 523-537, (2013).

12. A. Koltsova, B. Tunçer, G. Schmitt, eCAADe, 2, (2013).

13. J.J Gibson, The ecological approach to visual perception: classic edition (2014) 